\title{
Airway inflammation and mannitol challenge test in COPD
}

\author{
Selma B de Nijs ${ }^{1 *}$, Niki Fens ${ }^{1}$, Rene Lutter ${ }^{1,2}$, Erica Dijkers ${ }^{1}$, Frans H Krouwels ${ }^{3}$, Barbara S Smids-Dierdorp ${ }^{1,2}$, \\ Reindert P van Steenwijk', Peter J Sterk'
}

\begin{abstract}
Background: Eosinophilic airway inflammation has successfully been used to tailor anti-inflammatory therapy in chronic obstructive pulmonary disease (COPD). Airway hyperresponsiveness (AHR) by indirect challenges is associated with airway inflammation. We hypothesized that AHR to inhaled mannitol captures eosinophilia in induced sputum in COPD.
\end{abstract}

Methods: Twenty-eight patients (age $58 \pm 7.8 \mathrm{yr}$, packyears $40 \pm 15.5$, post-bronchodilator FEV $77 \pm 14.0 \%$ predicted, no inhaled steroids $\geq 4$ wks) with mild-moderate COPD (GOLD I-II) completed two randomized visits with hypertonic saline-induced sputum and mannitol challenge (including sputum collection). AHR to mannitol was expressed as response-dose-ratio (RDR) and related to cell counts, ECP, MPO and IL-8 levels in sputum.

Results: There was a positive correlation between RDR to mannitol and eosinophil numbers $(r=0.47, p=0.03$ ) and level of IL-8 ( $r=0.46, p=0.04)$ in hypertonic saline-induced sputum. Furthermore, significant correlations were found between RDR and eosinophil numbers $(r=0.71, p=0.001)$, level of ECP ( $r=0.72, p=0.001), I L-8(r=0.57$, $p=0.015)$ and MPO ( $r=0.64, p=0.007)$ in sputum collected after mannitol challenge. ROC-curves showed $60 \%$ sensitivity and $100 \%$ specificity of RDR for $>2.5 \%$ eosinophils in mannitol-induced sputum.

Conclusions: In mild-moderate COPD mannitol hyperresponsiveness is associated with biomarkers of airway inflammation. The high specificity of mannitol challenge suggests that the test is particularly suitable to exclude eosinophilic airways inflammation, which may facilitate individualized treatment in COPD.

Trial registration: Netherlands Trial Register (NTR): NTR1283

\section{Introduction}

Chronic obstructive pulmonary disease (COPD) is an inflammatory airway disease characterized by nonreversible airflow limitation [1]. Airflow limitation is usually progressive and associated with an abnormal inflammatory response of the lungs to noxious particles or gasses. The treatment options in COPD are still limited and current efforts focus on therapy targeted to particular phenotypes of the disease [1]. A non-invasive, standardised way to measure and monitor airway inflammation in COPD is hypertonic saline-induced sputum [2]. Analysis of induced sputum provides information about cell counts (eosinophils, neutrophils,

\footnotetext{
* Correspondence: S.B.deNijs@amc.uva.nl

${ }^{1}$ Department of Respiratory Medicine, Academic Medical Centre and University of Amsterdam, Meibergdreef 9, Amsterdam, 1105 AZ, The Netherlands

Full list of author information is available at the end of the article
}

lymphocytes, macrophages) and cell activity by mediator concentrations (e.g. ECP, MPO and IL-8).

In COPD patients the identification of sputum eosinophilia has shown to be of clinical value as it predicts a response to corticosteroids [3-5]. Furthermore, guiding inhaled steroid therapy by sputum eosinophil counts leads to a reduction in exacerbations in COPD, without an increase in steroid dose [6]. These observations demonstrate the value of identifying inflammatory subphenotypes in the treatment of COPD. However, the application of sputum analysis is somewhat limited by the requirement of lab facilities and the not-directly available results. Therefore, there is a need for adequate surrogate markers of airway inflammation in COPD.

Airway hyperresponsiveness (AHR) may serve as a surrogate measure of airway inflammation, since it is associated with the presence of inflammatory cells and
C Biomed Central

C 2011 de Nijs et al; licensee BioMed Central Ltd. This is an Open Access article distributed under the terms of the Creative Commons Attribution License (http://creativecommons.org/licenses/by/2.0), which permits unrestricted use, distribution, and reproduction in any medium, provided the original work is properly cited. 
release of mediators in the airways [7]. In particular, this holds for indirect challenges, amongst which dry powder mannitol challenge is relatively easy to apply [8,9]. Local mannitol deposition results in an osmotic change, likely to induce the release of mediators from inflammatory cells in the airways [10]. Studies in asthma showed that AHR to mannitol is indeed related to the degree of eosinophilic airway inflammation and is sensitive to treatment with inhaled corticosteroids [11-13]. Interestingly, a proof of concept study demonstrated that mannitol challenge might also be useful in identifying COPD patients who will most likely benefit from inhaled corticosteroids [14]. This may suggest that AHR to mannitol identifies the degree of eosinophilic inflammation in COPD.

We postulated that AHR to mannitol captures eosinophilic airway inflammation in adults with mild to moderate COPD. Our aim was to test this hypothesis by examining the relationship between AHR to mannitol and markers of inflammation in hypertonic saline-induced sputum, blood and exhaled air. As secondary aim, we investigated whether similar relations can be observed when using spontaneously produced sputum during or directly after the mannitol challenge itself. Finally, we constructed receiver operating characteristic (ROC) curves using AHR against sputum eosinophilia in COPD.

\section{Methods}

\section{Patients}

Thirty-two patients with mild to moderately severe COPD were included from two respiratory clinics in Amsterdam, The Netherlands. The definition of COPD was based on GOLD [1]. Inclusion criteria were symptoms of dyspnea, chronic cough or sputum production, current or exsmoker with at least 20 packyears of smoking history, postbronchodilator $\mathrm{FEV}_{1}>1.5$ liter and $>50 \%$ of predicted value, $\mathrm{FEV}_{1} / \mathrm{FVC}<0.70$ and clinically stable for $\geq 4$ weeks prior to recruitment. Exclusion criteria were (inhaled) steroid therapy or antibiotic treatment or exacerbation or chest infection $\leq 4$ weeks prior to recruitment, treatment with $\beta$-blockers, respiratory disease other than COPD including known asthma or allergic rhinitis and contraindications for challenge testing according to international guidelines [15]. Patients were asked to withhold strenuous exercise and smoking for $6 \mathrm{hrs}$ and eating for $2 \mathrm{hrs}$; caffeine and short-acting bronchodilators for $8 \mathrm{hrs}$; longacting bronchodilators for $48 \mathrm{hrs}$; short-acting anticholinergics for $24 \mathrm{hrs}$; long-acting anti-cholinergics and anti-histamines for $72 \mathrm{hrs}$; and leukotriene antagonists for 4 days prior to the mannitol challenge.

The study was approved by the Hospital Medical Ethics Committee and all patients gave their written informed consent. The study was registered in the Netherlands trial register under NTR 1283, was designed, performed and analysed by the authors, and was not sponsored by others than the Academic Medical Centre, Amsterdam, The Netherlands itself.

\section{Study design}

The study had a cross-sectional design with two studies days comprising randomized challenges with hypertonic saline and mannitol (figure 1). At a separate screening visit, inclusion and exclusion criteria were examined, postbronchodilator ( $400 \mu \mathrm{g}$ salbutamol) spirometry was performed and diffusion capacity was measured.

The sequence of the two study visits was randomized [interval (median (range)):7(7-15) days]. On one day sputum was induced by hypertonic saline and a venous blood sample was obtained. On the other day exhaled nitric oxide was measured first, followed by assessment of atopy and mannitol challenge testing.

\section{Measurements \\ Lung function}

Spirometry (MasterscreenPneumo; Jaeger; Würzburg, Germany) was performed by a trained respiratory technician according to the latest recommendations [16]. Diffusion capacity of the lung for carbon monoxide $\left(D_{L}\right.$, $\mathrm{CO})$ was measured according to the recommendations using the single breath method and was corrected for haemoglobin [17].

\section{Mannitol challenge}

Mannitol challenge was performed using a commercially available kit (Pharmaxis Ltd; Sydney, Australia) as described by Anderson et al [8]. Patients inhaled sequential doses of $5,10,20,40,80,160,160$ and 160 $\mathrm{mg}$ of mannitol via the inhaler. The test stopped when $15 \%$ fall in $\mathrm{FEV}_{1}$ was achieved or the cumulative dose of $635 \mathrm{mg}$ had been administered. Response-dose-ratio (RDR) was calculated as the\%fall in $F V_{1}$ at the last dose, divided by the total cumulative dose mannitol (\% fall.mg) in milligrams administered [18].

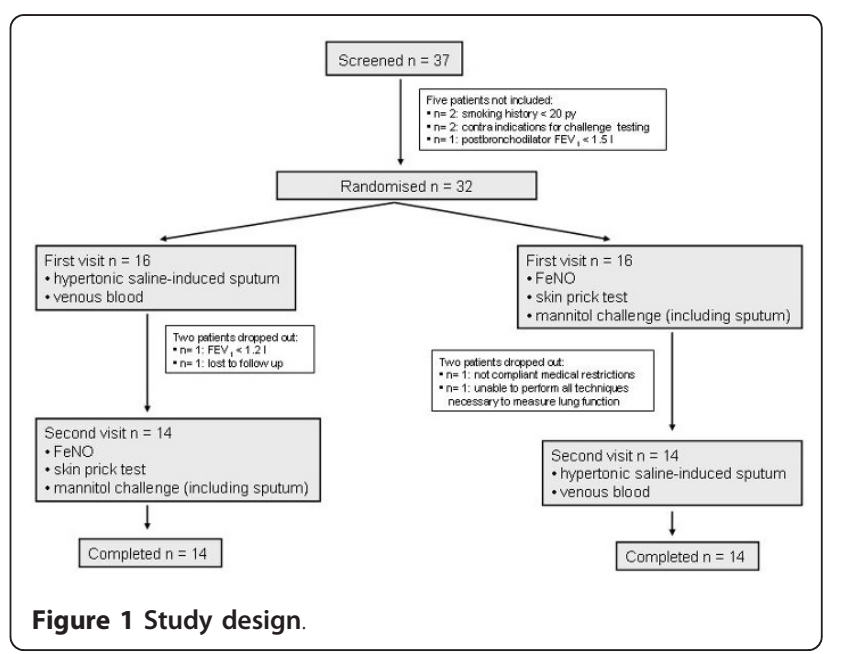


If a patient had to cough spontaneously during the mannitol challenge, he or she was asked to expectorate. This sputum was labeled as mannitol-induced sputum.

\section{Sputum induction and processing}

Prior to sputum induction, patients inhaled $200 \mu \mathrm{g}$ salbutamol. Sputum was induced by inhalation of $\mathrm{NaCl}$ $4.5 \%$ during $3 \times 5$ min intervals [19]. This sputum was labeled as induced sputum.

Whole sputum samples were processed according to a protocol that has been validated in our laboratory [20]. Differential cell counts were expressed as the percentage of non-squamous cells. Absolute cell numbers were calculated as $(\%$ cell $\times$ total cell count)/sputum weight. Sputum samples containing $>80 \%$ non-squamous cells were excluded from analysis.

All sputum cell counts were performed by one experienced and qualified technician blinded to the clinical details. As an extra control $10 \%$ of the samples were analyzed by a second technician.

\section{Analysis of soluble markers in sputum supernatant}

Levels of eosinophil cationic protein (ECP; detection limit $>60 \mathrm{pg} / \mathrm{ml}$ ), myeloperoxidase (MPO; detection limit $>1.5 \mathrm{ng} / \mathrm{ml}$ ), interleukin-8 (IL-8; detection limit $>19.1 \mathrm{pg} / \mathrm{ml})$ and alpha-2-macroglobulin $\left(\alpha_{2} \mathrm{M}\right.$; detection limit $>2.1 \mathrm{mg} / \mathrm{ml}$ ) were measured by enzyme-linked immunosorbent assays (ELISA) [21,22].

\section{Exhaled Nitric Oxide (FeNO)}

FeNO was measured with a portable rapid-response chemoluminescent analyser (flow rate $50 \mathrm{~mL} / \mathrm{s}$; NIOX System, Aerocrine, Sweden) according to recent guidelines [23].

\section{Statistical analysis}

The relationship between AHR to mannitol (RDR) and the markers of airway inflammation were analyzed using Pearson's correlation coefficient $\left(r_{p}\right)$. Non-normally distributed data were log-transformed for further analysis. If no cells were counted, a value of 0.1 was taken before log-transformation. Receiver operating characteristic (ROC) curves were constructed, using RDR against eosinophilic vs non eosinophilic COPD (threshold 2.5\% sputum eosinophils). Wilcoxon signed rank test and Bland-Altman analysis was used to compare cell counts of the two sputum samples.

A sample size estimation showed that the detectable value of the correlation ( $r$ ) under the alternative hypothesis with a sample of 23 patients $(n)$ is between 1-0.55 (power $=0.808$; alpha $=0.05)$. Therefore, thirty-two patients were recruited taking into account an expected $10 \%$ drop-out rate and a $20 \%$ probability of missing or non-valid data.

\section{Results}

Twenty-eight of the 32 patients completed the study (table 1). Four patients dropped out for reasons of:
Table 1 Patient characteristics I

\begin{tabular}{ll}
\hline & $\mathbf{n = 2 8}$ \\
\hline Male/Female $(n)$ & $23 / 5$ \\
Gold I/II $(n)$ & $12 / 16$ \\
Age (years) & $58 \pm 7.8$ \\
Current/ex-smoker $(n)$ & $12 / 16$ \\
Smoking history (pack years) & $40 \pm 15.5$ \\
Inhaled corticosteroids before study $(n)$ & 14 \\
Postbronchodilator FEV 1 (L) & $2.57 \pm 0.6$ \\
Postbronchodilator FEV 1 (\%predicted) & $77 \pm 14.0$ \\
FEV ${ }_{1} /$ FVC & $0.55 \pm 0.08$ \\
Atopy $(n)$ & 3 \\
$D_{L, C O}$ (\% predicted) & $65 \pm 14.7$ \\
\hline
\end{tabular}

Values are expressed as mean \pm SD.

Gold, Global Initiative for Chronic Obstructive Lung Disease.; FEV ${ }_{1}$, forced expiratory volume in $1 \mathrm{~s}$; FVC, forced vital capacity.; DLCO, Diffusion capacity lung for carbon monoxide.

non-compliance with medication restrictions $(\mathrm{n}=1)$, lost to follow up ( $\mathrm{n}=1), \mathrm{FEV}_{1}<1.2$ litre prior to challenge ( $\mathrm{n}$ $=1$ ) and inability to perform all techniques necessary to measure lung function $(\mathrm{n}=1)$. Two out of 28 mannitol challenges were not completed for reasons of coughing $(\mathrm{n}=1)$ and tiredness $(\mathrm{n}=1)$, but these patients were included since this was not an exclusion criterion. Hypertonic saline-induced sputum was collected in 28 patients and mannitol-induced sputum in 21 patients.

Correlation of inflammatory markers in hypertonic salineinduced sputum and blood with AHR to mannitol

The baseline values for airway hyperresponsiveness and inflammatory markers are presented in table 2. Five hypertonic saline-induced sputum samples were excluded from analyses as a result of $>80 \%$ non-squamous cells on differential cell counts. There was a significant positive correlation between the degree of AHR to mannitol (RDR mannitol) and eosinophil counts $(r=$ $0.47, \mathrm{p}=0.03$, figure 2 ) per gram hypertonic salineinduced sputum and with IL-8 levels $(r=0.46, \mathrm{p}=$ $0.04)$. The correlation between RDR mannitol and blood eosinophils was borderline significant $(\mathrm{r}=0.38, \mathrm{p}=$ 0.06 , figure 2). No other correlations between RDR mannitol and hypertonic saline-induced sputum parameters were found (Table 3). In addition, a significant, positive association between RDR mannitol and the level of FeNO ( $r=0.67, p=0.0002$, figure 2) was observed. When using $\mathrm{PD}_{15}$ to mannitol, the correlation coefficients with sputum and blood eosinophils counts were $-0.38(\mathrm{p}=0.09)$ and $-0.43(\mathrm{p}=0.03)$, respectively.

\section{Mannitol- induced sputum markers}

Two out of 21 sputum samples were excluded from analyses as a result of $>80 \%$ non-squamous cells on differential cell counts. There were strongly significant 
Table 2 Patient characteristics II- Airway hyperresponsiveness (AHR) and airway inflammation

\begin{tabular}{|c|c|}
\hline Subjects & $n=28$ \\
\hline \multicolumn{2}{|l|}{ Airway responsiveness $(n=26)$} \\
\hline - AHR to mannito ${ }^{*}(n)$ & 18 \\
\hline - RDR mannitol (\%/mg) & $0.044(0.0204-0.0605)$ \\
\hline - Max dose of mannitol (mg) & $395(315-635)$ \\
\hline - $\mathrm{PD}_{15}$ mannitol** & $331(196-635)$ \\
\hline \multicolumn{2}{|l|}{ Fraction Exhaled Nitric Oxide } \\
\hline - FeNO (ppb) & $14(9-22.5)$ \\
\hline \multicolumn{2}{|l|}{ Sputum $(n=23)$} \\
\hline - Eosinophils (\%) & $0.8(0.4-3.1)$ \\
\hline - Lymphocytes (\%) & $1.4(1.0-2.4)$ \\
\hline - Macrophages (\%) & $18.8(12.8-22.2)$ \\
\hline - Neutrophils (\%) & $77.2(70.8-86.0)$ \\
\hline - Total cell count (x10\%/g) & $1.6(0.5-2.8)$ \\
\hline \multicolumn{2}{|l|}{ Blood $(n=28)$} \\
\hline - Eosinophils (\%) & $2.7(1.8-4.3)$ \\
\hline - Neutrophils (\%) & $55.9(49.8-61.8)$ \\
\hline
\end{tabular}

Values are expressed as median and interquartile range.

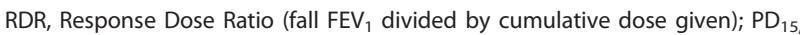
Provocation Dose of mannitol to cause a $15 \%$ fall in $\mathrm{FEV}_{1}$; pbb, parts per billion.

*: positive reaction to mannitol: $\mathrm{PD}_{15}<635 \mathrm{mg}$; *: including 8 patients who did not reach a $\mathrm{PD}_{15}$, we used an assigned value of $635 \mathrm{mg}$

positive correlations between RDR mannitol and the absolute and relative numbers of eosinophils and the level of ECP in mannitol-induced sputum $(\mathrm{r}=0.71, \mathrm{p}=$ $0.001 ; \mathrm{r}=0.60, \mathrm{p}=0.008 ; \mathrm{r}=0.72, \mathrm{p}=0.001$, respectively) (Figure 3$)$. In addition, RDR mannitol was related to the levels IL-8 $(\mathrm{r}=0.57, \mathrm{p}=0.015)$ and MPO $(\mathrm{r}=$ $0.64, \mathrm{p}=0.007$ ) (Table 3).

Inflammatory markers as obtained by hypertonic- and mannitol challenge were generally well correlated (Table 4). The limits of agreement by Bland and Altman analyses for eosinophil counts and log ECP were -5.7-8.6\% and $-0.73-0.72$, respectively.
Table 3 Correlation between AHR to mannitol expressed by the response-dose ratio (RDR) and markers of airway inflammation

\begin{tabular}{|c|c|c|}
\hline & $r$ & $p$ - value \\
\hline $\mathrm{FEV}_{1}$ (\% predicted) & -0.09 & 0.67 \\
\hline Log FeNO & 0.67 & $0.0002^{*}$ \\
\hline \multicolumn{3}{|c|}{ Hypertonic saline-induced sputum } \\
\hline $\log \left(10^{4} / g\right)$ eosinophils & 0.47 & $0.03^{*}$ \\
\hline Log $\left(10^{4} / \mathrm{g}\right)$ lymphocytes & 0.18 & 0.45 \\
\hline $\log \left(10^{4} / \mathrm{g}\right)$ macrophages & 0.27 & 0.24 \\
\hline $\log \left(10^{4} / g\right)$ neutrophils & 0.25 & 0.28 \\
\hline $\log \left(10^{4} / g\right)$ epithelial cells & 0.38 & 0.10 \\
\hline $\log (n g / m l) E C P$ & 0.39 & 0.09 \\
\hline $\log (p g / m l) ~ I L-8$ & 0.46 & $0.04^{*}$ \\
\hline $\log (n g / m l) M P O$ & 0.33 & 0.14 \\
\hline \multicolumn{3}{|l|}{ Mannitol- induced sputum } \\
\hline $\log \left(10^{4} / \mathrm{g}\right)$ eosinophils & 0.71 & $0.001^{*}$ \\
\hline $\log (n g / m l) E C P$ & 0.72 & $0.001^{*}$ \\
\hline $\log (p g / m l) ~ I L-8$ & 0.57 & $0.015^{*}$ \\
\hline 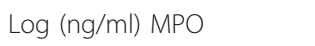 & 0.64 & $0.007^{*}$ \\
\hline \multicolumn{3}{|l|}{ Venous blood } \\
\hline Log (\%) eosinophils & 0.38 & 0.06 \\
\hline Log (\%) neutrophils & -0.23 & 0.26 \\
\hline
\end{tabular}

$\mathrm{RDR}$ is taken as the maximal\% fall in $\mathrm{FEV}_{1}$ per cumulative dose; correlation: Pearsons correlation coefficient; FeNO: fraction exhaled nitric oxide in parts per billion. ${ }^{*} \mathrm{p}<0.05$.

\section{ROC curves}

The overall accuracy of RDR to mannitol for the assessment of eosinophilic or non eosinophilic COPD, described as the area under the ROC curve (Figure 4), was $67 \%$ (95\% CI, 33.6 to $97.5 \%$ ) for hypertonic salineand $80 \%$ (95\% CI, 47.7 to $112.3 \%$ ) for mannitol-induced sputum. At RDR of $0.08 \%$ fall.mg the sensitivity and specificity for $>2.5 \%$ eosinophils in hypertonic salineinduced sputum was $50 \%$ (95\% CI, 11.8 to $88.2 \%$ ) and 93\% (95\% CI, 68 to 99.8\%), respectively. For mannitolinduced sputum the sensitivity and specificity was $60 \%$
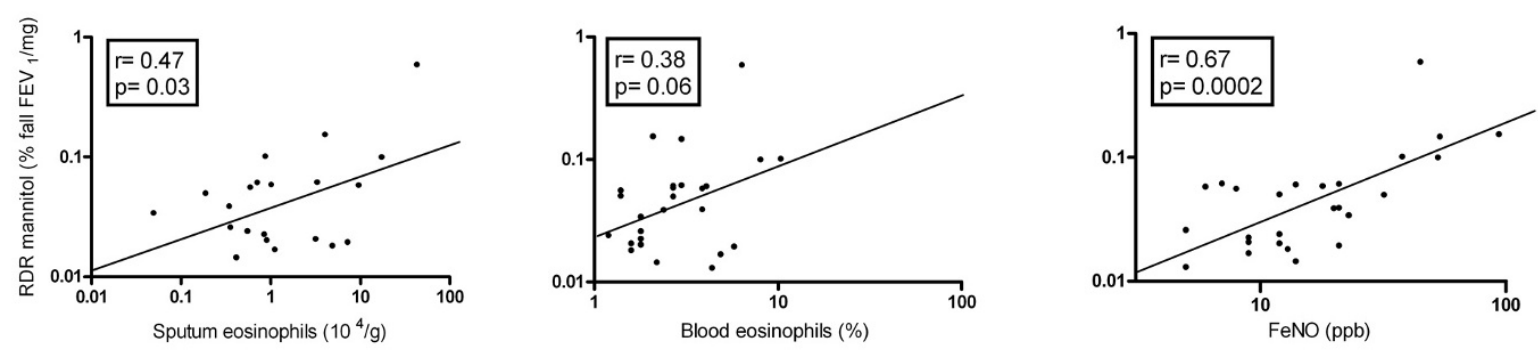

Figure 2 Correlation AHR to mannitol and eosinophils in hypertonic saline-induced sputum (left), blood eosinophils (middle) and fraction exhaled nitric oxide (right) 

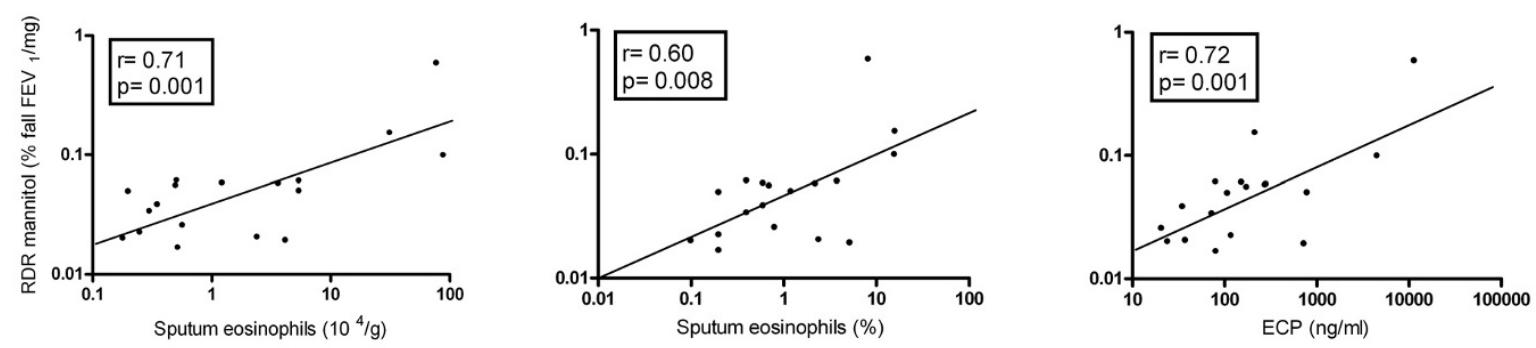

Figure 3 Correlation AHR to mannitol and the absolute (left) and relative (middle) amount of eosinophils and ECP (right) in mannitolinduced sputum.

(95\% CI, 14.7 to $94.7 \%$ ) and $100 \%$ (95\% CI, 75.3 to $100 \%$ ) respectively (Figure 4 ). When using a cut-point of $2.0 \%$ eosinophils we observed sensitivities of $44 \%$ (95\% CI, 13.7 to $78.8 \%$ ) and $43 \%$ (95\% CI, 9.0 to $81.6 \%)$ with specificities of $100 \%$ (95\% CI, 73.5 to $100.0 \%$ ) and $100 \%$ (95\% CI, 71.5 to $100 \%)$ for hypertonic saline- and mannitol- induced sputum, respectively.

\section{Discussion}

In this group of mild to moderate COPD patients, AHR to inhaled mannitol was consistently associated with eosinophil counts in hypertonic saline- as well as mannitol-induced sputum. In addition, we observed associations between AHR to mannitol and soluble markers of inflammation in sputum. Our results suggest that mannitol challenge identifies inflammatory subphenotypes in COPD, in particular those patients without eosinophilic inflammation due to the high specificity of the test. This may facilitate individualized treatment in COPD.

To our knowledge, this is the first study assessing the relationship between airway hyperresponsiveness to inhaled mannitol and markers of airway inflammation in sputum and exhaled air in patients with COPD. These observations extend previous findings in COPD using
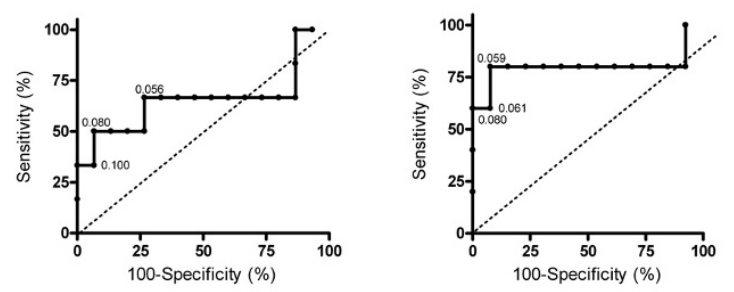

Figure 4 ROC curve. The curve of sensitivity against 100-specificity is based on using reactivity to mannitol, given as RDR values (\%fall. $\mathrm{mg}$ ), to predict eosinophilic COPD (>2.5\%) in hypertonic saline (left) and mannitol-induced (right) sputum. Dotted line: line of identity. adenosine 5'-monophosphate (AMP), in which a correlation between AHR to AMP and eosinophils in sputum was observed [24]. Interestingly, a similar correlation between RDR to mannitol and sputum eosinophils was recently reported in patients with asthma, also showing absence of eosinophilia in patients without mannitol hyperresponsiveness [13]. Hence, mannitol challenge appears to provide valuable information on the inflammatory profile in both patients with COPD and asthma.

In our study, particular attention was paid to methodological aspects such as selection of COPD patients, design and methods. The patients were derived from a clinical population rather than an epidemiological one, in order to strengthen the applicability of our findings. All patients were well characterised by using subjective and objective criteria. This included the presence of symptoms, fixed airway obstruction and smoking history. The full range in sputum eosinophils counts was 0.1 to $7.4 \%$, which is similar to previous studies in COPD [3-5]. To exclude any confounding effects of inhaled corticosteroids on mannitol challenge, the patients who used inhaled corticosteroids stopped this medication for 4 weeks $[9,11]$. In order to answer the research question accurately, we performed mannitol challenge and sputum induction on separate days. In addition, we examined sputum expectorated after the mannitol itself, which confirmed our results. Furthermore, as inflammatory markers we used both, the presence of inflammatory cells and markers of cell activation. This provided consistent associations.

Nevertheless, our study has limitations. First, we could not obtain adequate sputum samples in all patients at all time points. Even though the power of the study was adequate to address the primary objectives, it may not have been adequate to examine our secondary objective. Second, we can not exclude that our COPD group included patients who also had asthma. We excluded those with a previous history of asthma, but this may not have sufficed. However, all patients had a smoking 
Table 4 Induced sputum total and differential cell count and mediators when collected with hypertonic saline or mannitol (18 paired samples)

\begin{tabular}{llll}
\hline & Hypertonic saline & Mannitol induced & $r$ \\
\hline Eosinophils $\left(10^{4} / \mathrm{g}\right)$ & $1.1(0.5-6.5)$ & $0.9(0.3-7.5)$ & $0.81\left(\mathrm{p}=<0.001^{*}\right)$ \\
Lymphocytes $\left(10^{4} / \mathrm{g}\right)$ & $1.8(1.0-7.0)$ & $1.9(1.0-3.9)$ & $0.37(\mathrm{p}=0.132)$ \\
Macrophages $\left(10^{4} / \mathrm{g}\right)$ & $31.7(13.2-48.7)$ & $20.5(12.6-34.4)^{* *}$ & $0.71\left(\mathrm{p}=0.001^{*}\right)$ \\
Neutrophils $\left(10^{4} / \mathrm{g}\right)$ & $111.1(59.4-231.5)$ & $108.1(58.4-160.1)$ & $0.75\left(\mathrm{p}=<0.001^{*}\right)$ \\
Epithelial cells $\left(10^{4} / \mathrm{g}\right)$ & $21.3(14.5-71.2)$ & $25.5(12.8-42.3)$ & $0.61\left(\mathrm{p}=0.009^{*}\right)$ \\
Total cell count $\left(\times 10^{6} / \mathrm{g}\right)$ & $1.6(0.8-2.6)$ & $1.4(0.8-2.0)$ & $0.73\left(\mathrm{p}=0.001^{*}\right)$ \\
Gram sputum & $6.9(5.2-10.9)$ & $4.0(2.0-9.0)^{* *}$ & $0.60\left(\mathrm{p}=0.006^{*}\right)$ \\
ECP $(\mathrm{ng} / \mathrm{ml})$ & $147.5(89.5-492.3)$ & $125.8(64.1-277.2)$ & $0.85\left(\mathrm{p}=<0.001^{*}\right)$ \\
IL-8 $(\mathrm{pg} / \mathrm{ml})$ & $1925.5(534.8-7076.0)$ & $1595(862.8-3357.2)$ & $0.72\left(\mathrm{p}=0.001^{*}\right)$ \\
MPO $(\mathrm{ng} / \mathrm{ml})$ & $4529.7(1779.4-7414.8)$ & $5174.3(1203.0-11933)$ & $0.84\left(p=<0.001^{*}\right)$
\end{tabular}

Data expressed as median and interquartile range; $r=$ Pearsons correlation coefficient:

* = significant; ${ }^{* *}=$ significantly different (Wilcoxon rank test).

history, fixed airflow limitation, met the COPD GOLD criteria, and were diagnosed and treated as COPD patients. Third, the patients needed to stop the inhaled corticosteroids in order to examine unbiased disease markers. Therefore, the test performance cannot be generalized to COPD patients on inhaled steroids. This will require a separate study. Finally, we did not include a second mannitol challenge for examining reproducibility of our results, which is a limitation of our design.

How can we interpret these results? Mannitol is an osmotic stimulus that causes airway narrowing by release of bronchoconstrictor mediators such as leukotrienes, prostaglandins and histamine $[25,26]$. The source of these mediators is likely to be mast cells and eosinophils in the airways as both these cell types release mediators in vitro in response to mannitol $[10,11,27]$. Mast cells and eosinophils are not unimportant in COPD and may contribute to the fluctuations of airways obstruction as observed e.g. during exacerbations [28-31]. We did not observe associations of mannitol responsiveness with neutrophil counts in sputum or blood, but did found significant correlations with sputum IL-8 and MPO. This may suggest that epithelial cell and neutrophil activity are also involved in determining the airway narrowing to inhaled mannitol in COPD. Interestingly, mannitol responsiveness was more strongly associated with FeNO than with sputum eosinophils. However, we did not find a significant association between the latter two parameters. This is in keeping with the data by Siva et al. [6]. Our results suggest that mannitol responsiveness is a better marker of eosinophilic inflammation than FeNO in COPD.

Notably, we observed that most COPD patients produced adequate sputum samples during the mannitol challenge. This occurred even in absence of encouraging the patients to expectorate. Therefore, the success rate of obtaining mannitol-induced sputum may well be improved by adjusting the standard operating procedure of the test. Our findings extend a recent study in asthma, showing adequate sputum samples after mannitol challenge [32]. Inhaled mannitol changes osmolarity and reduces viscoelasticity, surface tension, contact angle and the solids content of sputum [33]. This may explain why $75 \%$ of the patients gave up sputum during mannitol challenge. Our results suggest that mannitol activated eosinophils, neutrophils and epithelial cells. Hence, even though AHR to mannitol was associated with eosinophilic airway inflammation, it is likely to be a more pleiotropic stimulus within the airways.

What are the clinical implications of our study? Eosinophilic airway inflammation predicts the response of COPD patients to systemic and inhaled corticosteroids $[4,5]$. In addition, inhaled steroid therapy guided by sputum eosinophils reduces exacerbation rate in patients with COPD [6]. Our results suggest that mannitol challenge can identify COPD patients without eosinophilic airway inflammation, who not likely to benefit from inhaled steroid therapy [6]. This subphenotype of patients cannot be distinguished from other patients with COPD on clinical grounds or lung function criteria. Therefore, mannitol challenge may qualify as a feasible alternative in the monitoring of anti-inflammatory therapy in COPD. The high specificity $(100 \%)$ in combination with limited sensitivity indicates that mannitol responsiveness is particularly suitable to exclude sputum eosinophilia in COPD. Indeed, inhaled steroids appear to be ineffective in COPD patients with the lowest responsiveness to mannitol [14]. Therefore, mannitol responsiveness may support decisions to refrain from inhaled steroid treatment, thereby potentially preventing overtreatment of COPD. This requires a randomized controlled study in COPD comparing a treatment strategy based on AHR to mannitol with the currently recommended treatment strategy based on clinical 
markers only. It remains to be established whether mannitol challenge can also be an outcome measure of the efficacy of steroids in COPD, as has been shown in asthma [12]. Finally, our data suggest that the assessment of AHR and airway inflammation in COPD can be combined in a single test. This would have large practical advantages, not only in clinical research, but also regarding the guidance and monitoring of anti-inflammatory therapy in clinical practice.

\section{Conclusions}

We conclude that airway responsiveness to mannitol can be used to rule out eosinophilic airway inflammation in patients with mild to moderate COPD who are not treated with inhaled corticosteroids. These finding suggests that mannitol challenge is a candidate for the guidance and monitoring of individualized, anti-inflammatory therapy in COPD, as an alternative to sputum eosinophils.

\section{List of abbreviations}

AHR: airway hyperresponsiveness; ECP: eosinophil cationic protein; FeNO: fraction exhaled nitric oxide; $F_{E V}$ : forced expiratory volume in one second: $\mathrm{FEV}_{1} / \mathrm{FVC}$ : forced vital capacity divided by the forced expiratory volume in one second; FVC: forced vital capacity; ICS: inhaled corticosteroids; IL-8: interleukin-8; MPO: myeloperoxidase; $\mathrm{PD}_{15}$ : provocation dose to cause a fall in $\mathrm{FEV}_{1}>15 \%$; RDR: response dose ratio; ROC: receiver operating characteristic.

\section{Acknowledgements}

We would like to thank the participants in the study and Tamara Dekker for determining the inflammatory parameters. This study was financially supported by the Academic Medical Centre, Amsterdam, without external sponsor.

\section{Author details}

'Department of Respiratory Medicine, Academic Medical Centre and University of Amsterdam, Meibergdreef 9, Amsterdam, 1105 AZ, The Netherlands. ${ }^{2}$ Department of Experimental Immunology, Academic Medical Centre and University of Amsterdam, Meibergdreef 9, Amsterdam, 1105 AZ, The Netherlands. ${ }^{3}$ Department of Pulmonology, Onze Lieve Vrouwe hospital, Oosterpark 9, Amsterdam, 1091 AC, The Netherlands.

\section{Authors' contributions}

SdN was the main author of the paper and developed the study design and subject recruitment, collected study data and performed statistical analysis. All other authors contributed significantly to the design of the study, the collection and assessment of clinical data and development of this paper. All authors contributed significantly to the development of the manuscript and all have seen and approved the final version and take responsibility for the content.

\section{Competing interests}

The authors declare that they have no competing interests.

Received: 15 October 2010 Accepted: 18 January 2011

Published: 18 January 2011

\section{References}

1. Rabe KF, Hurd S, Anzueto A, Barnes PJ, Buist SA, Calverley P, Fukuchi Y, Jenkins C, Rodriguez-Roisin R, van WC, Zielinski J: Global strategy for the diagnosis, management, and prevention of chronic obstructive pulmonary disease: GOLD executive summary. Am J Respir Crit Care Med 2007, 176:532-555.
2. Djukanovic R, Sterk PJ, Fahy JV, Hargreave FE: Standardised methodology of sputum induction and processing. Eur Respir J Supp/ 2002, 37:1s-2s.

3. Pizzichini E, Pizzichini MM, Gibson P, Parameswaran K, Gleich GJ, Berman L, Dolovich J, Hargreave FE: Sputum eosinophilia predicts benefit from prednisone in smokers with chronic obstructive bronchitis. Am J Respir Crit Care Med 1998, 158:1511-1517.

4. Brightling CE, Monteiro W, Ward R, Parker D, Morgan MD, Wardlaw AJ, Pavord ID: Sputum eosinophilia and short-term response to prednisolone in chronic obstructive pulmonary disease: a randomised controlled trial. Lancet 2000, 356:1480-1485.

5. Leigh R, Pizzichini MM, Morris MM, Maltais F, Hargreave FE, Pizzichini E: Stable COPD: predicting benefit from high-dose inhaled corticosteroid treatment. Eur Respir J 2006, 27:964-971.

6. Siva R, Green RH, Brightling CE, Shelley M, Hargadon B, McKenna S, Monteiro W, Berry M, Parker D, Wardlaw AJ, Pavord ID: Eosinophilic airway inflammation and exacerbations of COPD: a randomised controlled trial. Eur Respir J 2007, 29:906-913.

7. Cockcroft DW, Davis BE: Mechanisms of airway hyperresponsiveness. J Allergy Clin Immunol 2006, 118:551-559.

8. Anderson SD, Brannan J, Spring J, Spalding N, Rodwell LT, Chan K, Gonda I, Walsh A, Clark AR: A new method for bronchial-provocation testing in asthmatic subjects using a dry powder of mannitol. Am J Respir Crit Care Med 1997, 156:758-765.

9. Brannan JD, Anderson SD, Perry CP, Freed-Martens R, Lassig AR, Charlton B: The safety and efficacy of inhaled dry powder mannitol as a bronchial provocation test for airway hyperresponsiveness: a phase 3 comparison study with hypertonic (4.5\%) saline. Respir Res 2005, 6:144

10. Brannan JD, Anderson SD, Freed R, Leuppi JD, Koskela H, Chan HK: Nedocromil sodium inhibits responsiveness to inhaled mannitol in asthmatic subjects. Am J Respir Crit Care Med 2000, 161:2096-2099.

11. Brannan JD, Koskela H, Anderson SD, Chan HK: Budesonide reduces sensitivity and reactivity to inhaled mannitol in asthmatic subjects. Respirology 2002, 7:37-44.

12. Koskela HO, Hyvarinen L, Brannan JD, Chan HK, Anderson SD: Sensitivity and validity of three bronchial provocation tests to demonstrate the effect of inhaled corticosteroids in asthma. Chest 2003, 124:1341-1349.

13. Porsbjerg C, Brannan JD, Anderson SD, Backer V: Relationship between airway responsiveness to mannitol and to methacholine and markers of airway inflammation, peak flow variability and quality of life in asthma patients. Clin Exp Allergy 2008, 38:43-50.

14. Leuppi JD, Tandjung R, Anderson SD, Stolz D, Brutsche MH, Bingisser R, Perruchoud AP, Surber C, Knoblauch A, Andersson M, Greiff L, Chan HK, Tamm M: Prediction of treatment-response to inhaled corticosteroids by mannitol-challenge test in COPD. A proof of concept. Pulm Pharmacol Ther 2005, 18:83-88.

15. Sterk PJ, Fabbri LM, Quanjer PH, Cockcroft DW, O'Byrne PM, Anderson SD, Juniper EF, Malo JL: Airway responsiveness. Standardized challenge testing with pharmacological, physical and sensitizing stimuli in adults. Report Working Party Standardization of Lung Function Tests, European Community for Steel and Coal. Official Statement of the European Respiratory Society. Eur Respir J Suppl 1993, 16:53-83.

16. Miller MR, Hankinson J, Brusasco V, Burgos F, Casaburi R, Coates A, Crapo R, Enright $P$, van der Grinten CP, Gustafsson P, Jensen R, Johnson DC, Maclntyre N, McKay R, Navajas D, Pedersen OF, Pellegrino R, Viegi G, Wanger J: Standardisation of spirometry. Eur Respir J 2005, 26:319-338.

17. Maclntyre N, Crapo RO, Viegi G, Johnson DC, van der Grinten CP, Brusasco V, Burgos F, Casaburi R, Coates A, Enright P, Gustafsson P, Hankinson J, Jensen R, McKay R, Miller MR, Navajas D, Pedersen OF, Pellegrino R, Wanger J: Standardisation of the single-breath determination of carbon monoxide uptake in the lung. Eur Respir J 2005, 26:720-735.

18. O'Connor G: Analysis of Dose-Response Curves to Methacholine. An approach Suitable for Population Studies. Am Rev Respir Dis 1987, 136:1412-1417.

19. in't Veen J, de Gouw HW, Smits HH, Sont JK, Hiemstra PS, Sterk PJ, Bel EH: Repeatability of cellular and soluble markers of inflammation in induced sputum from patients with asthma. Eur Respir J 1996, 9:2441-2447.

20. Boorsma M, Lutter $R$, van de Pol MA, Out TA, Jansen HM, Jonkers RE: Repeatability of inflammatory parameters in induced sputum of COPD patients. COPD 2007, 4:321-329.

21. Bresser $P$, Out $T A$, van $A L$, Jansen HM, Lutter R: Airway inflammation in nonobstructive and obstructive chronic bronchitis with chronic 
haemophilus influenzae airway infection. Comparison with noninfected patients with chronic obstructive pulmonary disease. Am J Respir Crit Care Med 2000, 162:947-952.

22. Out TA, Jansen HM, van Steenwijk RP, de Nooijer MJ, van de Graaf EA, Zuijderhoudt FM: ELISA of ceruloplasmin and alpha-2-macroglobulin in paired bronchoalveolar lavage fluid and serum samples. Clin Chim Acta 1987, 165:277-288

23. ATS/ERS recommendations for standardized procedures for the online and offline measurement of exhaled lower respiratory nitric oxide and nasal nitric oxide. Am J Respir Crit Care Med 2005, 171:912-930, 2005.

24. Rutgers SR, Timens W, Tzanakis N, Kauffman HF, van der Mark TW, Koeter GH, Postma DS: Airway inflammation and hyperresponsiveness to adenosine $5^{\prime}$-monophosphate in chronic obstructive pulmonary disease. Clin Exp Allergy 2000, 30:657-662.

25. Brannan JD, Gulliksson M, Anderson SD, Chew N, Kumlin M: Evidence of mast cell activation and leukotriene release after mannitol inhalation. Eur Respir J 2003, 22:491-496.

26. Brannan JD, Gulliksson M, Anderson SD, Chew N, Seale JP, Kumlin M: Inhibition of mast cell PGD2 release protects against mannitol-induced airway narrowing. Eur Respir J 2006, 27:944-950.

27. Gulliksson M, Palmberg L, Nilsson G, Ahlstedt S, Kumlin M: Release of prostaglandin D2 and leukotriene $\mathrm{C} 4$ in response to hyperosmolar stimulation of mast cells. Allergy 2006, 61:1473-1479.

28. Fujimoto K, Yasuo M, Urushibata K, Hanaoka M, Koizumi T, Kubo K: Airway inflammation during stable and acutely exacerbated chronic obstructive pulmonary disease. Eur Respir J 2005, 25:640-646.

29. Grashoff WF, Sont JK, Sterk PJ, Hiemstra PS, de Boer WI, Stolk J, Han J, van Krieken JM: Chronic obstructive pulmonary disease: role of bronchiolar mast cells and macrophages. Am J Pathol 1997, 151:1785-1790.

30. Louis RE, Cataldo D, Buckley MG, Sele J, Henket M, Lau LC, Bartsch P, Walls AF, Djukanovic R: Evidence of mast-cell activation in a subset of patients with eosinophilic chronic obstructive pulmonary disease. Eur Respir J 2002, 20:325-331.

31. Andersson CK, Mori M, Bjermer L, Lofdahl CG, Erjefalt JS: Alterations in lung mast cell populations in patients with chronic obstructive pulmonary disease. Am J Respir Crit Care Med 2010, 181:206-217.

32. Wood LG, Powell H, Gibson PG: Mannitol challenge for assessment of airway responsiveness, airway inflammation and inflammatory phenotype in asthma. Clin Exp Allergy 2010, 40:232-241.

33. Daviskas E, Anderson SD, Young IH: Inhaled mannitol changes the sputum properties in asthmatics with mucus hypersecretion. Respirology 2007, 12:683-691.

doi:10.1186/1465-9921-12-11

Cite this article as: de Nijs et al: Airway inflammation and mannitol challenge test in COPD. Respiratory Research 2011 12:11.

\section{Submit your next manuscript to BioMed Central and take full advantage of:}

- Convenient online submission

- Thorough peer review

- No space constraints or color figure charges

- Immediate publication on acceptance

- Inclusion in PubMed, CAS, Scopus and Google Scholar

- Research which is freely available for redistribution

Submit your manuscript at www.biomedcentral.com/submit
C Biomed Central 